\title{
Software development for emergency bed management
}

\author{
Desenvolvimento de software para gerenciamento de leitos na urgência e emergência \\ Desarrollo de software para la gestión de lechos de urgencia y de emergencia
}

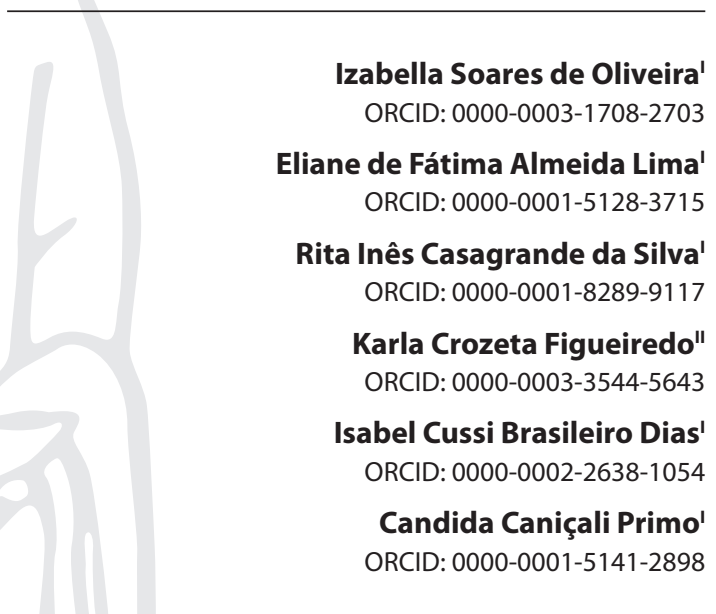

'Universidade Federal do Espírito Santo. Vitória, Espírito Santo,

Brazil.

"Universidade Federal do Paraná. Curitiba, Paraná, Brazil.

How to cite this article:

Oliveira IS, Lima EFA, Silva RIC, Figueiredo KC, Dias ICB,

Primo CC. Software development for emergency bed management. Rev Bras Enferm. 2021;74(Suppl 5):e20200055. doi: http://dx.doi.org/10.1590/0034-7167-2020-0055

Corresponding author: Izabella Soares de Oliveira

E-mail: izabellasoaresdeoliveira@gmail.com

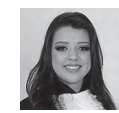

EDITOR IN CHIEF: Antonio José de Almeida Filho ASSOCIATE EDITOR: Priscilla Broca

Submission: 05-28-2020 Approval: 10-06-2020

\begin{abstract}
Objective: to describe the process of developing a software for emergency bed management. Methods: a participatory research based on User-Centered Design in four stages: 1) definition of requirements and structure elaboration; 2 ) generation of alternatives and prototyping; 3) tests; 4) implementation. Seminars were held with health professionals between May 21 , 2018 and May 31, 2019 for the preparation and assessment of software content. Results: the software CuidarTech KRONOS was developed for emergency bed management using the kanban methodology. Final considerations: this software will assist professionals' and managers' decision-making providing more reliable data to enable the improvement of work processes and the quality of patient care. Developing a bed management software is innovative in the health field, and no articles were found describing this methodology. Descriptors: Health Care Coordination and Monitoring; Nursing; Emergency Service, Hospital; Information Systems; Quality of Health Care.
\end{abstract}

\section{RESUMO}

Objetivo: descrever o processo de desenvolvimento de um software para gerenciamento de leitos na urgência e emergência. Métodos: pesquisa participativa fundamentada no Design Centrado no Usuário em quatro etapas: 1) definição de requisitos e elaboração da estrutura; 2) geração das alternativas e prototipagem; 3) testes; 4) implementação. Realizados seminários com profissionais de saúde entre 21 de maio de 2018 e 31 de maio de 2019 para a elaboração e avaliação do conteúdo do software. Resultados: foi desenvolvido o software CuidarTech KRONOS para gerenciamento dos leitos da urgência e emergência, utilizando a metodologia kanban. Considerações finais: o software auxiliará na tomada de decisão dos profissionais e gestores, fornecendo dados mais fidedignos para viabilizar a melhoria dos processos de trabalho e da qualidade da assistência ao paciente. O desenvolvimento do software para gerenciamento de leitos é inovador na área da saúde, e não foram encontrados artigos que descrevessem essa metodologia.

Descritores: Regulação e Fiscalização em Saúde; Enfermagem; Serviço Hospitalar de Emergência; Sistemas de Informação; Qualidade da Assistência à Saúde.

\section{RESUMEN}

Objetivo: describir el proceso de desarrollo de un software para la gestión de lechos en emergencia. Métodos: investigación participativa basada en Diseño Centrado en el Usuario en cuatro etapas: 1) definición de requisitos y elaboración de la estructura; 2) generación de alternativas y prototipos; 3) pruebas; 4) implementación. Seminarios realizados con profesionales de la salud entre el 21 de mayo de 2018 y el 31 de mayo de 2019 para la preparación y evaluación de contenidos de software. Resultados: CuidarTech KRONOS fue desarrollado para la gestión de lechos de emergências utilizando la metodología kanban. Consideraciones finales: el software ayudará en la toma de decisiones de profesionales y gerentes, proporcionando datos más confiables para permitir la mejora de los procesos de trabajo y la calidad de la atención al paciente. El desarrollo de software de gestión de lechos es innovador en salud y no se encontraron artículos que describan esta metodología. Descriptores: Regulación y Fiscalización en Salud; Enfermería; Servicio de Urgencia en Hospital; Sistemas de Información; Calidad de la Atención de Salud. 


\section{INTRODUCTION}

Assistance regulation emerged as a management tool, considered complex, linked to the actions of regulation, inspection, control, audit, and assessment, and the governance function of state authorities. It aims to organize the production and distribution of health resources, goods and services through regulatory tools, such as protocols, risk classification and prioritization criteria, in order to ensure the population's interest. Its aims to guarantee the right to health, access with efficiency, efficacy, and effectiveness, provision of quality health actions and services to meet the population's demand, with the resources available satisfactorily, as determined by the objectives of the Unified Health System (SUS - Sistema Único de Saúde) ${ }^{(1-2)}$.

Supply and demand monitoring is carried out by the central regulator, which acts through health actions and services at different levels of care, at state, regional and municipal levels. In hospitals, the Internal Regulatory Nucleus (NIR - Núcleo Interno de Regulação) acts in interface with the regulation centers, being responsible for bed management, a device whose purpose is to reduce hospitalization length of stay, increase patient turnover, optimize occupation and provide new vacancies for dammed demands, aiming at a quality service to users ${ }^{(3-4)}$.

In order to facilitate the monitoring of bed management, tools have been adapted to assist the work process, one of which is kanban, which controls hospital stay. Kanban - a Japanese word with the meaning of cards - is a tool derived from Lean thinking, adapted for the health sector. It allows hospital bed management, in order to visualize patients hospitalized in a sector and classify them by color-coded cards, manually changed according to the pre-defined length of stay and the institutional reality ${ }^{(5)}$.

Another possible tool is computerized information systems, which facilitate the collection, storage, retrieval, monitoring and dissemination of information in an agile, safe and more reliable way, assisting in the quality of managerial, operational and decision-making functions. Looking for the integration between kanban and computational resources, the software CuidarTech KRONOS was developed.

\section{OBJECTIVE}

To describe the process of developing a software for emergency bed management.

\section{METHODS}

\section{Ethical aspects}

This study was approved by the Research Ethics Committee, with CAAE (Certificado de Apresentação para Apreciação Ética Certificate of Presentation for Ethical Consideration).

\section{Theoretical-methodological framework}

The User-Centered Design method was used, according to ABNT ISO-TR 16982: 2014 standard ${ }^{(6)}$.

\section{Type of study}

This is participatory research based on User-Centered Design. Active user participation is one of the key principles $^{(7)}$. This methodology consists of developing solutions through the development of products that are easy to handle and meet users'needs and requirements ${ }^{(8)}$. During the computerized system development, there is interaction between users and designers, in order to achieve the expected characteristics ${ }^{(9)}$.

This research followed the Consolidated Criteria for Reporting Qualitative Research (COREQ).

\section{Methodological procedures}

\section{Study setting}

This study was carried out in a university hospital located in the Southeast Region of Brazil, in partnership with the Laboratory of Health Technologies (CuidarTech ${ }^{\circledR}$ ), the Laboratory and Observatory of Project Ontologies (LOOP') of Universidade Federal do Espírito Santo (UFES), and the Taruíra Lab of Instituto Federal do Espírito Santo (IFES). The hospital has exclusive care through SUS, being a reference for procedures of medium and high complexity. It has a physical structure of 324 beds, of which 249 are for hospitalization and 75 for observation. Of these, 10 beds are in the emergency sector (SUE - Setor de Urgência e Emergência).

\section{Data collection and organization}

Developing a bed management software was carried out in four stages: 1) definition of content, requirements and structure elaboration; 2) generation of alternatives for implementation and prototyping; 3 ) tests; 4) implementation.

To define the software content, a literature review was carried out in Latin American \& Caribbean Literature in Health Sciences (LILACS), International Literature in Health Sciences (MEDLINE) and Cumulative Index to Nursing and Allied Health Literature (CINAHL) databases. To this end, Health Sciences Descriptors (DeCS - Descritores em Ciências da Saúde) and Medical Subject Headings (MeSH) were used: health regulation and inspection, health services administration, beds, hospital beds, emergency medical services, quality of care indicators, information and nursing systems. Studies related to hospital bed management, kanban and health technologies were listed. The Brazilian National Emergency Care Policy (PNAU), the Brazilian National Regulation Policy (Política Nacional de Regulação) and the Brazilian National Hospital Care Policy (PNHOSP - Política Nacional de Atenção Hospitalar) were also used.

After surveying the scientific literature, seminars were held with representatives of professionals from the Health Regulation and Assessment Sector (SRAS) and the emergency sector, defined by the institution, from May 21, 2018 to May 31, 2019, for content elaboration and assessment and definition of the software requirements. The seminars were conducted by the researchers, one of whom was an SRAS servant. The six seminars took place in a private room at the study hospital, with an average duration of one hour and ten minutes. At the last meeting, the software was presented for assessment by consensus by the group. 
Then, to organize the software's requirements and structure, CuidarTech $^{\circledR}$, LOOP ${ }^{\circledR}$ and Taruíra Lab teams met with the Process Management and Information Technology Sector (SGPTI - Setor de Gerenciamento de Processos e Tecnologia da Informação) to define the tool's programming and modeling data according to the standards used by the institution.

The project was designed to obtain data from two sources: the first, from University Hospital Management Application (AGHU Aplicativo de Gestão do Hospital Universitário), a system in which patients are admitted to the functional unit "emergency room". The hospitalization data is automatically captured by the software, updating it automatically and encoding it with the colors defined for kanban, according to length of stay established by the team. The second source is information provided by the team of professionals in the emergency sector and assistance regulation. The names of patients provided in the figures have been encrypted and are fictitious, obtained from AGHU test database.

Interaction design alternatives were generated for the software's functionalities, with a view to adopting free and open technologies, whenever possible, and following the standards used by the institution. Functional prototypes (alpha, beta and pre-release) of the functionalities were integrated into the general structure of the software. The tests were performed during the development stage using the usability standard and Nielsen's heuristics ${ }^{(9)}$. The textual proposal for preparing the content was registered at the National Library and the software was registered at the Brazilian National Institute of Industrial Program (INPI - Instituto Nacional de Programa Industrial).

\section{RESULTS}

In the first stage of content definition, requirements and elaboration of the structure, nine professionals participated, $66.7 \%$ from the health regulation and assessment sector and $33.3 \%$ from the emergency sector. The average age of members, at the time of the research, was 35.9 years, ranging from 30 to 46 years, so that most (55.6\%) were between 30 to 35 years old. According to the data, $100 \%$ were female; $66.7 \%$ were nurses; $22.2 \%$ were doctors; $11.1 \%$ were managers; $11.1 \%$ had graduation as their maximum degree; $77.8 \%$ had a Lato Sensu graduate course; $11.1 \%$ had a Stricto Sensu graduate course. The average time passed since graduation was 7.8 years, and $22.2 \%$ completed it between 0 and five years, $44.5 \%$ between six and 10 years and $33.3 \%$ between 11 and 15 years. The average practice time in the field was 4.3 years, with $66.7 \%$ having practice time in their current practice area between 0 and 5 years and $33.3 \%$ between 6 and 10 years.

During the seminars, the group of professionals defined the content, requirements and the elaboration of the software structure, which was subdivided into objective, necessary requirements, mapping of modules, database and indicators, patient registration screen, main screen and screen for more detailed access. They defined that the software would be used in the desktop service, however a computational modeling was performed to later be adapted on mobile devices

Also, in the seminars, patient data to be provided from AGHU were defined: medical record number, patient's name, age, specialty, date of admission to SUE, length of stay, date of departure and reason for leaving SUE. The manually supplied data were also defined: reason for patients' length of stay, Fugulin's patient classification system (PCS), patient's origin and observations. The concept map expresses the screens' content to construct the software (Figure 1).

At this stage, the ideal length of stay for patients in SUE and the kanban coding were also determined, according to the institutional reality. The colors were thus defined: green, equivalent to less than or equal to 24 hours; yellow, greater than 24 hours and less than or equal to 72 hours; red, for more than 72 hours. It is justified by the choice of the 24-hour period, since the ideal time recommended by the Brazilian National Policy for Attention to Emergencies (Política Nacional de Atenção às Urgências) (10) to stay in an emergency room is between six and 24 hours. For yellow and red, the 72-hour limit corresponded, at the time of the research, to the average patients' length of stay in the hospital's SUE, 2.6 days.

In the definition phase of the software requirements, meetings were held with the hospital's SGPTI to define the computational modeling consistent with the standards used in the institution, request $\mathrm{AGHU}$ database and agree with the articulation between the teams for testing the software and support in tool implementation.

The second stage was the generation of the implementation and prototyping alternatives, being divided into Front-End, Back-End, and database sessions. The software modules and layouts were developed. In Front-End, the technologies used include Hypertext Markup Language (HTML), Cascading Style Sheets (CSS), Bootstrap, JavaScript, jQuery, jQuery DataTable, jQuery Ajax. For Back-End, PHP: Hypertext Preprocessor (PHP) and Laravel were used. In the database, the technology for data management was PostgreSQL.

Using the software consists of: when admitting a patient to AGHU, in the functional unit "Pronto-Socorro", the registration will be automatically directed to CuidarTech KRONOS in the "patient registration" screen. The number of patients pending registration will appear at the top of the "main screen" (Figure 2). Once selected, "patient registration" screen is accessed (Figure 3 and Figure 4). Some data are obtained from AGHU, such as name, medical record, age, specialty, date of hospitalization, and others are manually informed by the system users, with the reason for stay, Fugulin's PCS, patient's origin and observations. After filling in, the information is saved.

After approval on the "patient registration screen", the following data will appear on the "main screen" with the data: name, age, specialty, length of stay (in hours, days) and the reason for the stay. It is observed that the color of the line for patients changes to green, yellow or red according to the pre-defined residence length. To access or change the information, a patient is selected and the information is consulted on the "screen for more detailed access" (Figure 5). On this screen, data related to patients are displayed, including medical record numbers, names, ages, specialties, date of admission to SUE, length of stay, reason for stay, Fugulin's patient classification system, origin and observation, with the history by date and time of the modifications made. 


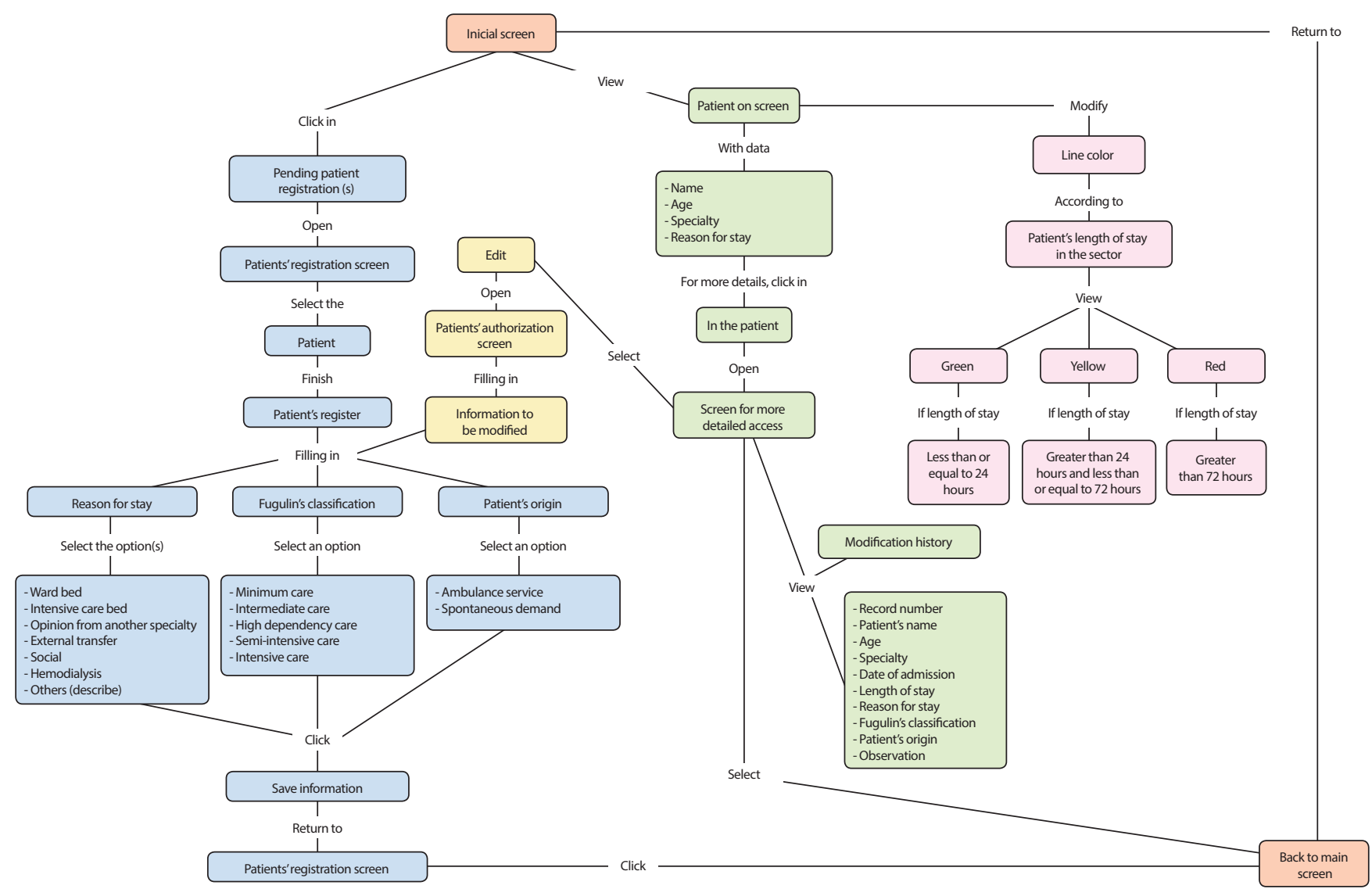

Figure 1 - Conceptual map of CuidarTech KRONOS, Vitória, Espírito Santo, Brazil

\section{KRONOS}

Existem 195 cadastro(s) de paciente(s) pendente(s)

\begin{tabular}{|c|c|c|c|c|}
\hline Mostrat $100=$ registros $p c$ & soggina & & & Pesquisar: \\
\hline NOME & IDADE & ESPECIAUDADE II & TEMPO DE PERMANÊNCAA I & MOTIVO DE PERMANÊNCIA NO SUE II \\
\hline $5927298977 \mathrm{C}$ & 60 & INF & Shr $2 \min$ & Social \\
\hline DAS9 AS8 6 CAB14 & 30 & $\mathrm{COB}$ & 2 ano(s) 5 mes(es) $4 \mathrm{~d} 18 \mathrm{hr} 30 \mathrm{~min}$ & Leito de UTL \\
\hline 696AZEATAOFB & 2 & UTN & Id 5hr 2min & Leito de enfermaria, Hemodialise, \\
\hline Mostrando de 1 d 3 de 3 regi & & & Relatorio & Anterior 1 próximo \\
\hline
\end{tabular}

Caption: Existem 195 cadastros(s) de paciente(s) pendentes - there are 195 patient registers pending; Mostrar "100" registros por página - show "100" register per page; Pesquisar - search; Nome - name; Idade - age; Especialidade - specialty; Tempo de permanência - length of stay; Motivo de permanência no SUE - reason for stay in SUE; INF-CHILD; Social - social; 2 ano(s) 5 mês(es) - 2 years and 5 months; Leito de UTI - ICU bed; UTN - NICU; Leito de enfermaria - ward bed; Hemodiálise - hemodialysis; Mostrando de 1 à 3 de 3 registro(s) - showing from 1 to 3 of 3 registers; Relatório report; Anterior-previous; Próximo-next.

Figure 2 - Main screen of CuidarTech KRONOS for monitoring the kanban tool in the emergency sector, Vitória, Espírito Santo, Brazil

The data obtained while using the software is stored in a database managed by PostgreSQL technology, and backup takes place in real time. Data can be extracted at any time and, based on them, reports with indicators, presented in numbers and graphs.

Data can be easily edited considering assistance's needs and developments. Handling the software does not require prior training, as it presents a friendly interface, easy to understand, which followed the institution's standards. The computers available in the service support its installation; after deployment by the Information Technology team, support will be required for system updates.
TELA DE CADASTRO DE PACIENTES

KRONOS

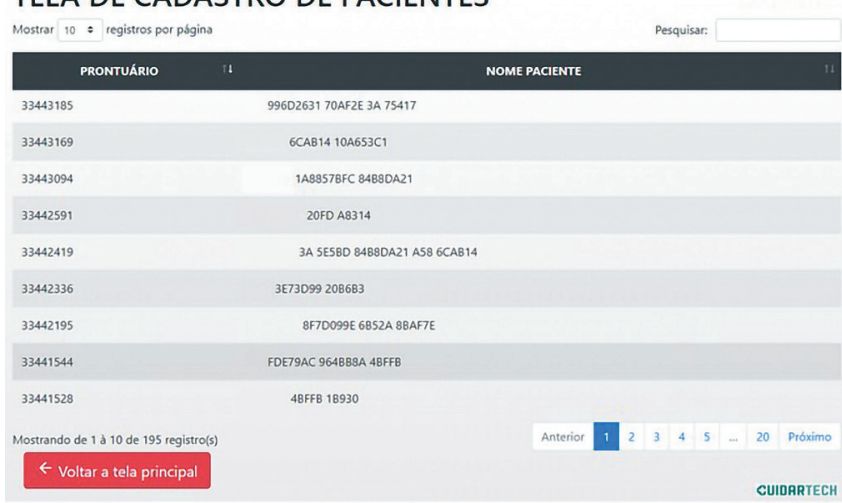

Caption: Tela de cadastro de pacientes - patients' registration screen; Mostrar " 10 " registros por página - show " 10 " registers per page; Prontuário - record; Nome Paciente - patient's name; Mostrando de 1 à 10 de 195 registro(s) - showing from 1 to 10 of 195 registers; Anterior-previous; Próximo - next; Volta a tela principal - back to main screen.

Figure 3 - Screen for accessing patient register of CuidarTech KRONOS for monitoring the kanban tool in the emergency sector, Vitória, Espírito Santo, Brazil

In the last seminar, the professionals approved the content and functionalities of the software, with everyone's agreement. Suggestions were accepted and corrections were made.

As for testing stage, the development team performed them using the usability standard and Nielsen's heuristics during the software development, and the detected problems were corrected. However, professionals still need to assess the tool in a real setting. Concerning last stage, the software is being implemented by the institution's Information Technology team. 


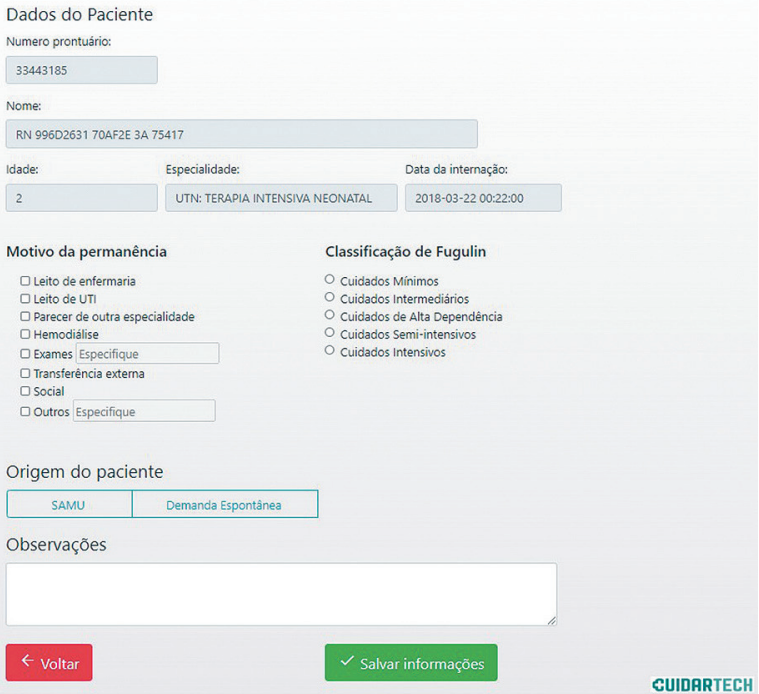

Caption: Tela de cadastro de pacientes - patients' registration screen; Dados do paciente patient data; Número prontuário - record name; Nome - name; Idade - age; Especialidade - specialty; Data da internação - date of admission; Motivo da permanência - reason for stay; Leito de enfermaria - ward bed; Leito de UTI - ICU bed; Parecer de outra especialidade - opinion from another specialty; Hemodiálise - hemodialysis; Exames "Especifique" - lab tests "specify" Transferência externa - external transfer; Social - social; Outros "Especifique" - others "specify"; Classificação de Fugulin - Fugulin's classification; Cuidados mínimos - minimum care; Cuidados intermediários - intermediate care; Cuidado de alta dependência - high dependency care Cuidados semi-intensivos - semi-intensive care; Cuidados intensivos - intensive care; Origem do paciente - patient's origin; SAMU - ambulance service; Demanda espontânea - spontaneous demand; Observações - observations; Voltar - back; Salvar informações - save information.

Figure 4 - Screen of patient registration of CuidarTech KRONOS for monitoring the kanban tool in the emergency sector, Vitória, Espírito Santo, Brazil

\section{KRONOS}

\section{$5927298977 C$}

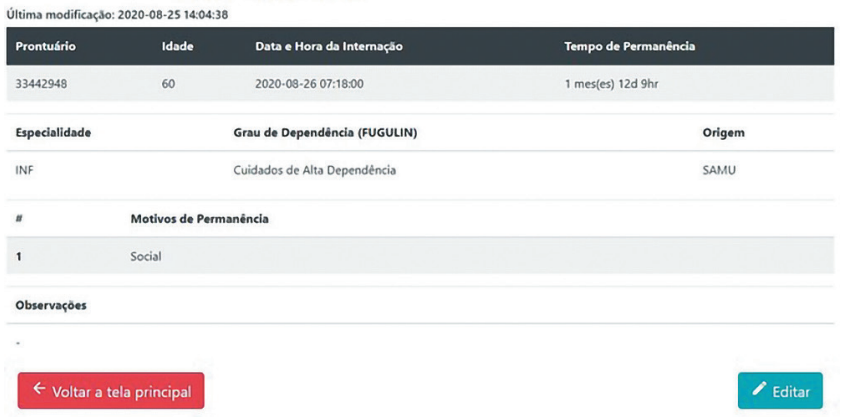

Histórico de Alterações

2020-09-25 14:04:35

Caption: Última data de modificação - last modification date; Prontuário - record; Idade - age Data e hora da internação-date and time at admission; Tempo de permanência-length of stay; 1 mês(es) $12 d 9 \mathrm{hr}-1$ month 12d 9hr; Especialidade - specialty; Grau de dependência (FU GULIN) - dependency degree (FUGULIN); Origem - origin; INF - CHILD; Cuidados de alta dependência high dependency care; SAMU - ambulance service; Motivos de permanência - reasons for stay; Social - social; Observações - observations; Volta a tela principal - back to main screen; Editar - edit; Histórico de alterações - modification history.

Figure 5 - Screen for more detailed access to patients of CuidarTech KRONOS for monitoring the kanban tool, Vitória, Espírito Santo, Brazil

\section{DISCUSSION}

Information systems have become indispensable for work processes in the health area, and the quality of this tool is related to the inclusion of professionals who will handle it in development. For this reason, the User-Centered Design method used in this study enabled the team to be integrated in the construction of a product that meets sectors' demands, as professionals act as informants, and guide the elaboration in order to provide developers with the maximum information essential to the existing ones ${ }^{(7,11)}$.

Associated with User-Centered Design, making a mapping protocol using focus groups or workshops/seminars to collect data provided the interaction between researcher and participants. Moreover, it allowed obtaining information through a participative discussion of all members, gathered in the same place, in a certain period of time, exchanging experiences and opinions, with the purpose of collectively building the research results ${ }^{(12-13)}$.

Technological innovation interferes in work processes and in health establishment management, causing transformation of care practices and improving the quality of patient care ${ }^{(14)}$. Recording information on a computer system becomes more reliable. The paper record has disadvantages, such as free presentation of the content expressed in the papers, which may be unreadable and non-standard, incomplete filling or loss of data, difficulty in consulting them and the demand for a place to be stored ${ }^{(15)}$.

Given these advantages, in the first phase of the research, construction of the software content mapping protocol, the group defined that the software development for monitoring kanban would facilitate the work process. Manually, it would take time and labor to keep it up to date. Moreover, CuidarTech KRONOS was developed to offer SUE and NIR assistance to direct patients to the necessary and appropriate resource, support professionals regarding the adopted procedures and offer the improvement of the quality of patient care.

In bed management, developing and adapting tools that support access prioritization become important. Computational technologies and mobile applications have helped in reducing health risks, in directing professional conduct for decision-making, in supporting team conduct ${ }^{(16)}$. These tools provide access to information in real time, helping to solve health problems and needs $s^{(8)}$. Furthermore, they provide the development of strategies and new workflows to increase patient turnover and, consequently, the efficiency of bed management and reduction of hospital costs ${ }^{(16)}$.

This research on the implementation of technology to manage inpatient units concluded that the tool provided integration between assistance and management, guided professionals regarding nursing sizing and generated a positive impact on the quality of care and on the workplace ${ }^{(17)}$. It was found, in another study, that implementing software with the nursing process in inpatient units helped in care and management interface, reducing the time for bureaucratic activities, and the professionals' time management was optimized. Moreover, it contributed to decision-making, analysis of assistance and generation of a database for future consultations ${ }^{(18)}$.

CuidarTech KRONOS is an innovative technology that has unprecedented tools in relation to other software available on the market, since it has an interface of assistance and management activities. Through this interface, professionals view data in real time to support emergency bed management in order to identify 
the reasons for patients' stay in the sector, facilitate work, provide reliable data and reduce bureaucracy. It also has a database to generate reports with hospital indicators. Based on these data, it allows to trace new workflows in order to improve the quality of care and direct patients to the necessary resource. The software also includes Fugulin's patient classification system. Therefore, it will be able to subsidize the allocation of human resources regarding the degree of patient dependence, resulting in the organization of services and planning related to nursing care.

\section{Study limitations}

The limitations of the study include incompatibility of time and impossibility of participation by all professionals in the sectors of assistance regulation and emergency in order to expand the discussions and views about the software developed. Another limitation was the need to hold several meetings with several managers of the institution to demonstrate the importance of software development and establish support for its implementation.

\section{Contributions to nursing, health, and public policies}

As contributions, CuidarTech KRONOS can be implemented in other institutions through interoperability assessment, collaborating for health professionals' and managers' decision-making regarding the process of patient hospitalization, transfer and discharge in a timely manner, with ethical and legal support. It also contributes to strengthen SUS based on this computational regulatory tool, which enables providing health services with efficiency, efficacy, and effectiveness. For managers, the software directs planning and assessment, in addition to standardizing actions, work processes and generating result indicators.

\section{FINAL CONSIDERATIONS}

This research described the development process of CuidarTech KRONOS for emergency bed management using User-Centered Design. Developing an information system is complex; therefore, the choice of this methodology provided the involvement of the team that will operationalize it since construction, to be consistent with the service's demands and meet the requirements necessary for work.

The software will facilitate visualizing patients admitted to the emergency department, assisting in the conduct of professionals and in the issuance of reports on hospital indicators in order to establish new workflows. Consequently, it will lead to an improvement in work processes, the quality of patient care and a reduction in costs with hospital admissions.

The software development strategy for bed management is innovative in the health field, and no articles were found that described the standardized methodology. Therefore, this study may support other similar research, adapting the tool's content to the local reality.

\section{FUNDING}

The financial subsidy for software development was made by Espírito Santo Research and Innovation Foundation (FAPES Fundação de Amparo à Pesquisa e Inovação do Espírito Santo) and partially by the researcher herself.

\section{REFERENCES}

1. Gamarra TPN. Contribuições epistemológicas da ergologia para a regulação em saúde. Trab Educ Saúde. 2014;12(3):483-98. doi: 10.1590/1981-7746-sip00001

2. Peiter CC, Lanzoni GMM, Oliveira WF. Regulação em saúde e promoção da equidade: o Sistema Nacional de Regulação e o acesso à assistência em um município de grande porte. Saúde Debate. 2016;40(111):63-73. doi: 10.1590/0103-1104201611105

3. Barbosa DVS, Barbosa NB, Najberg E. Regulação em saúde: desafios à governança do SUS. Cad Saúde Colet. 2016;24(1):49-54. doi: $10.1590 / 1414-462 X 201600010106$

4. Gawryszewski AR, Oliveira DC, Gomes AMT. Acesso ao SUS: representações e práticas de profissionais desenvolvidas nas Centrais de Regulação. Physis Rev Saúde Colet[Internet]. 2012;22(1):119-40 [cited 2017 Jul 16]. Available from: http://www.redalyc.org/html/4008/400838236007/

5. Anschau F, Webster J, Roessler N, Fernandes EO, Klafke V, Silva CP, et al. Evaluation of clinical governance interventions on qualification of care and supply of beds in a large public hospital. Sci Med. 2017;27(2):1-7. doi: 10.15448/1980-6108.2017.2.26575

6. Associação Brasileira de Normas Técnicas. NBR 16982: ergonomia da interação humano-sistema: métodos de usabilidade que apoiam o projeto centrado no usuário. Rio de Janeiro. 2014.

7. Savi R, Souza CBC. Design centrado no usuário e o projeto de soluções educacionais. E-tech: Tecnologias para competitividade industrial [Internet]. 2015[cited 2017 Jul 16]; ; (EspDes). Available from: http://etech.sc.senai.br/index.php/edicao01/article/download/615/386/

8. Barra DCC, Paim SMS, Sasso GTMD, Colla GW. Métodos para desenvolvimento de aplicativos móveis em saúde: revisão integrativa da literatura. Texto Contexto Enferm. 2017;26(4):1-12. doi: 10.1590/0104-07072017002260017

9. Celerino VG, Tavares W. Avaliação do website móvel e desktop do Sistema Integrado de Bibliotecas de Pernambuco. Navus. 2018;8(4):156166. doi: 10.22279/navus.2018.v8n4.p156-166.732

10. Ministério da Saúde (BR). Política Nacional de Atenção às Urgências. Brasília: Ministério da Saúde; 2003.

11. Santana JC, Nóbrega MML, Oliveira JS, Soares MJGO. Nursing consultation software for hypertensive users of the Family Health Strategy. Rev Bras Enferm. 2018;71(5):2541-46. doi: 10.1590/0034-7167-2017-0174 
12. Araujo JL, Sant'Anna HC, Lima EFA, Fioresi M, Nascimento LCN, Primo CC. Mobile app for nursing process in a neonatal intensive care unit. Texto Contexto Enferm[Internet]. 2019 [cited 2020 Feb 03];28:e20180210. Available from: https:/www.scielo.br/pdf/tce/v28/1980-265X-tce-28-e20180210.pdf

13. Carvalho DS, Silva AGI, Ferreira SRM, Braga LC. Construção de tecnologia educacional para estomizados: enfoque no cuidado a pele periestoma. Rev Bras Enferm. 2019;72(2):447-54. doi: 10.1590/0034-7167-2016-0024

14. Moreira ACA, Teixeira FE, Araújo TL, Cavalcante TF, Silva MJ, Cruz ATCT. Desenvolvimento de software para o cuidado de enfermagem: revisão integrativa. JNUOL. 2016;10(supl.6):4942-50. doi: 10.5205/reuol.8200-71830-3-SM.1006sup201629

15. Lima LM, Santos SR. Prototype software for nursing records in a neonatal intensive care unit. Aquichan. 2015;15(1):31-43. doi: 10.5294/ aqui.2015.15.1.4

16. Raffa C, Malik AM, Pinochet LHC. Análise das variáveis do ambiente interno no gerenciamento de leitos em organizações privadas: aplicação do software nvivo. RAHIS. 2017;14(4). doi: 10.21450/rahis.v14i4.4427

17. Lorenzetti J, Gelbcke FL, Vandresen L. Tecnologia para gestão de unidades de internação hospitalares. Texto Contexto Enferm. 2016;25(2):111. doi: 10.1590/0104-07072016001770015

18. Domingos CS, Boscarol GT, Souza CC, Tannure MC, Chianca TCM, Salgado PO. Adaptação de software com o processo de enfermagem para unidades de internação. Rev Bras Enferm. 2019;72(2):418-25. doi: 10.1590/0034-7167-2018-0579 